\title{
PHILOSOPHY TVET DI ERA DERUPSI REVOLUSI INDUSTRI 4.0 DI INDONESIA
}

\author{
Unung Verawardina, Jalius Jama \\ 1), Pendidikan Teknolgi Informasi dan Komputer, Fakultas Pendidikan MIPATEK, IKIP PGRI \\ Pontianak, \\ 2) Pendidikan Teknolgi dan Kejuruan, Fakultas Teknik, Universitas Negeri Padang \\ Jalan Prof. Dr. Hamka Air Tawar Padang, Sumatera Barat \\ Email : unungverawardina@gmail.com
}

\begin{abstract}
Abstrak
Tujuan penulisan artikel ini adalah untuk mengkaji Philosophy TVET di era derupsi revolusi industri 4.0 di Indonesia, yang meliputi tentang bagaimana filsafat pendidikan kejuruan, TVET, pembelajaran di Abad XXI hingga Revolusi industri 4.0. Praksis pendidikan kejuruan di Indonesia lebih cendrung mengarah penggunaan mazab Prosser melalui filosfi esensialisme dan mazab Dewey filosofi pragmatis. Namun dalam perjalannyan perubahan-perubahan yang terjadi dalam pembelajaran Abad XXI dan perkembangan teknologi modern, maka peran TVET sebagai pendidikan dan pelatihan yang tujuanya mempersiapkan tenaga kerja sesuai kebutuhan dunia kerja memiliki tantangan tersendiri. TVET cenderung kefilosofi pragmatism, dan sepanjang perubahan yang terjadi pada perkembangan berbasis sains, teknologi dan rekayasa. Terkait dengan perkembangan teknologi yang modern ini merupakan ciri dari filosofi pragmatis rekonstruksi yakni reformasi sosial yang menghendaki budaya modern. Menjawab reformasi sistem TVET dibutuhkanya antisipatif terhadap perubahan Abad XXI, maka pembelajaran disesuai dengan 21st Century Skills. Revolusi Industri 4.0 menjadi era baru perindustrian yang banyak menggunakan teknologi virtual dan canggih, sehingga di era ini menjadi pendorong munculnya ide-ide baru, ciptaan baru maupun sesuatu yang lama dimodifikasi untuk berinovasi dalam mengembangkan teknologi baru. Oleh karena itu pendidikan kejuruan saat ini menghadapi tantangan yang cukup besar, maka pendidikan kejuruan mesti mempersiapkan segala hal dalam menghadapi transisi ini.
\end{abstract}

\section{Kata kunci: Philosophy TVET, pendidikan kejuruan, revolusi industri 4.0}

\section{Pendahuluan}

Secara umum tujuan utama dari pendidikan kejuruan dan vokasi adalah mempersiapkan tenaga kerja yang terampil. Di Indonesia sendiri menggunakan istilah pendidikan kejuruan untuk jenjang pendidikan menengah misalnya SMK/MAK dan pendidikan vokasi untuk pendidikan tinggi seperti lingkup Akademi, Sekolah Tinggi, Politeknik, Institut, dan Universitas. Secara yuridis dapat dilihat dalam Undang Undang Sistem Pendidikan Nasional (Sisdiknas) Nomor 20 Tahun 2003. Pasal 15 UU Sisdiknas.

Pendidikan Teknologi Kejuruan memiliki beberapa istilah di berbagai negara. Namun berdasarkan hasil kongres kedua 26-29 April 1999 dengan tema Technical and Vocational Education and Training: A Vision for the Twenty-first Century.Menghasilkan terminologi Technical and Vocational Education and Training (TVET) termasuk pendidikan vokasi meliputi pendidikan dan pelatihan formal, nonformal, dan informal. Hasil ini capaian dari kesepakatan bersama melalui deligasi yang dihadiri perwakilan Unseco, International Labour Organization (ILO), dan Unevoc. Maka dari itu dalam TVET pendidikan dan pelatihan berjalan seirama dimana TVET merupakan pendidikan dan pelatihan yang tujuanya mempersiapkan tenaga kerja sesuai kebutuhan dan permintaan lapangan kerja dalam hal ini adalah dunia usaha dan industri yang link and match.

Praksis pendidikan kejuruan dunia di motori dua tokoh terkemuka yaitu Charles Prosser dan John Dewey. Di Indonesia berdasarkan tujuan pendidikan kejuruan dalam UU Nomor 20 Tahun 2003 lebih mengarah kepada filosofi esensialisme oleh mazab Prosser, sedangkan dalam PP 19 Tahun 2005 yang menjelaskan tentang SKL SMK lebih mengarah kepada filosofinya pragmatisme oleh mazab Dewey. Perubahan-perubahan yang terjadi dalam pembelajaran Abad XXI memberi tantangan pada TVET dimana terjadinya pergeseran paradigma pengembangan sumber daya manusia melalui revolusi teknologi informasi dan komunikasi. Menurut Sudira (2018:17) Indonesia dan seluruh dunia dihadapkan pada 
tantangan perubahan lingkugan kerja dan cara kerja yang semakin disrutif di era revolusi industri 4.0. Implementasi pendidikan 4.0 ini membutuhkan keterampilan baru sehingga penyiapan SDM sebagai lulusan dari kejuruan dan vokasi harus memilki kompetensi sesuai bahkan memiliki multi kompetensi dengan perkembangan teknologi menjadi sebuah keharusan. Oleh karena itu peran TVET sebagai pendidikan dan pelatihan harus mampu untuk menghadapi perubahan tantangan tersebut melalui muatan pembelajaran Abad XXI menyesuaikan dengan perubahan di era industri 4.0.

\section{Metode}

Metode yang digunakan dalam pengumpulan data ini adalah metode (library research) melalui penelaahan berbagai sumber ilmiah dalam bentuk buku-buku, literatur-literatur, dan artikel ilmiah yang sesuai dengan kajian yang dibahas dalam artikel.

\section{Pembahasan}

\section{Filsafat Pendidikan Kejuruan}

Kata "vocational" berasal dari bahasa inggris yang memiliki arti kejuruan. Oleh karena itu pendidikan kejuruan memiliki makna yang sama dengan pendidikan vokasional. Di Indonesia sendiri menggunakan nomenklatur pendidikan kejuruan pada tingkat menengah misalnya SMK dan pendidikan vokasi pada tingkat pendidikan tinggi misalnya diploma. Pendidikan kejuruan dan vokasi berfokus pada mempersiapkan peserta didik untuk bekerja. Sedangkan TVET dalam nomenklatur pendidikan vokasional menjadi komprehensif digunakan dalam proses pendidikan dan pelatihan untuk dunia kerja, kegiatannya dilaksanakan di sekolah dan di tempat kerja.

Aristoteles (382-322SM) mendefinisikan filsafat sebagai pengetahuan tentang kebenaran. Filsafat juga diartikan sebagai usaha mendeskripsikan sifat dasar yang terdalam dan sesungguhnya dari kenyataan (Jalius Jama,2010). Filosofi Pendidikan kejuruan di Indonesia mengacu kepada teori Prosser tertanam dalam kurikulum berbasis kompetensi yang berkenaan dengan kompetensi kerja di industri. Perspektif filosofi esensialisme kurikulum dan pembelajaran dikembangkan berdasarkan kebutuhan bisnis dunia usaha dan industri yang juga tercerminka pada Kerangka Kualifikasi Nasional Indonesia (KKNI) di indonesia saat ini. Sedangkan melalui pengelompokkan program normatif, adaptif, dan produktif yang ada pada pendidikan kejuruan mengandung makna pragmatis dari teorinya dewey. Pembelajaran dalam filosofi pragmatisme mengkonstruksi pengetahuan berdasaran pengetahuan sebelumnya, mampu memecahkan masalah, memeprsiapkan kehidupan.

Secara filosofis tujuan pendidikan vokasi ada tiga macam, yaitu: (1) esensialisme, (2) pragmatis, dan (3) pragmatis rekonstruksi.Berikut segitiga filosofi TVET.

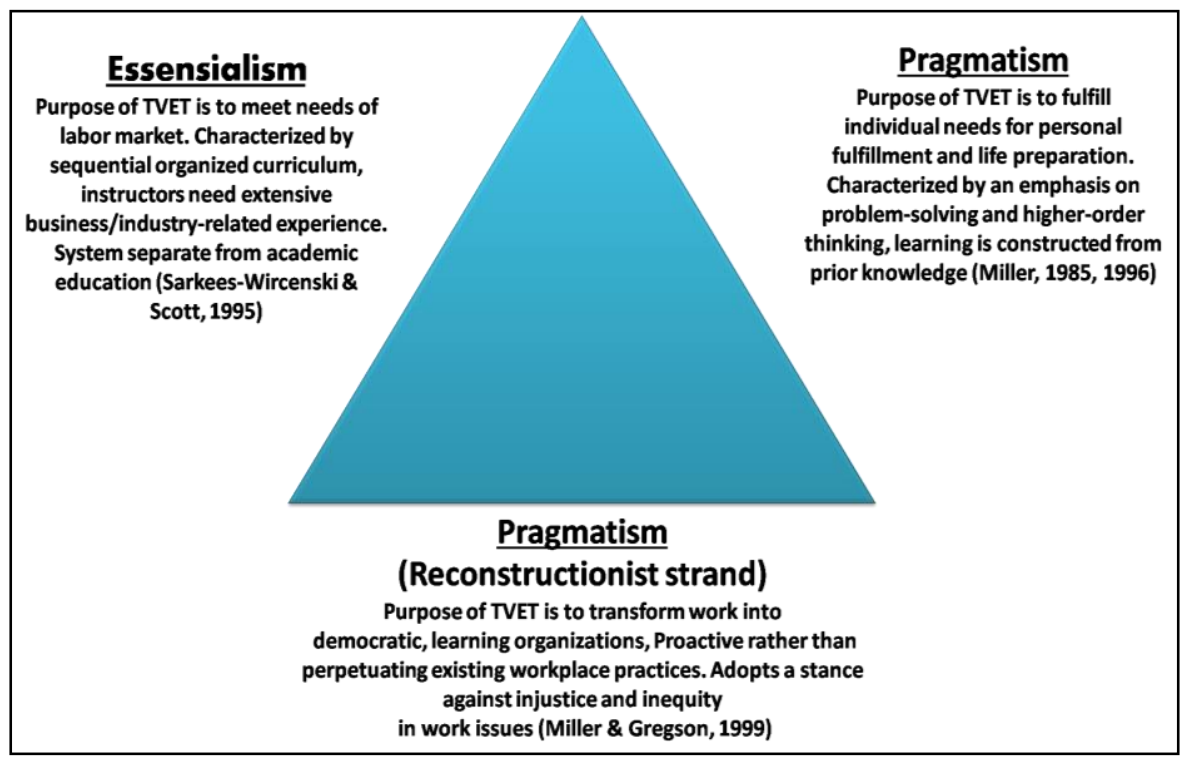




\section{Gambar 1. Segitiga Filosofi TVET}

Pada filosofi esensialisme menjelaskan bahwa TVET bertujuan untuk memenuhi kebutuhan dunia kerja, karakteristik kurikulum diorganisir secara sekuensial, pengajaran yang memerlukan pengalaman terkait bisnis atau industri, serta sistem pendidikan akademik dibuat secara terpisah. Pada filosofi pragmatisme tujuan TVET untuk memenuhi kebutuhan individu seseorang untuk mempersiapakan kehidupannya, karakteristiknya menekankan pada kemampuan pemecahan masalah, berpikir orde tinggi, mengkontsruksi pengetahuan sebelumnya. Sedangkan pada filosofi pragmatism rekonstruksionis strand tujuan TVET untuk melakukan transformasi masyarakat untuk masyarakat demokratis, belajar organisasi, bersifat proaktif, tidak mengekalkan diri hanya pada praktik-praktik ditempat dunia kerja saja, mengadopsi isu dan masalah ketidakadilan dan ketidak merataan terhadap masalah-masalah dunia kerja. Ketiga filosofi tersebut baik esensialisme, pragmatism dan pragmatism rekonstruksionis strand dapat dipilih dan diterapkan serta disesuaikan dengan cukup dari TVET. Berdasrkan ketiga filosifi tersebut TVET cenderung kefilosofi pragmatism (Sudira, 2016).

\section{Filsafat Pendukung TVET di Era Revolusi Industri 4.0}

TVET bermuara pada pendidikan dan pelatihan, dimana saat ini terjadinya reformasi sistem TVET yang mengarah pada peningkatan daya fleksibilitas, inovasi, produktivitas kebutuhan skill pasar dunia kerja, pelatihan dan pelatihan kembali pekerja dan calon pencari kerja pada semua sektor ekonomi baik formal maupun nonformal, perkembangan karakteristik dunia kerja seperti ini menuntut pembelajaran TVET terbangunnya suatu masyarakat yang memiliki sistem sosial dan sistem budaya berbasis sains, teknologi dan rekayasa. Menjawab reformasi sistem TVET tersebut dibutuhkanya antisipatif terhadap perubahan Abad XXI, maka pembelajaran disesuai dengan 21st Century Skills.

Filosofi pragmatisme merupakan filosofi yang diangap sesuai diterapkan pada TVET masa depan (Rojewski, 2009). Karena filosofi pragmatisme mendudukkan TVET sebagai pendidikan yang bertujuan untuk memenuhi kebutuhan individu dalam memenuhi seluruh kebutuhan hidupnya. Selain itu juga sejalan dengan karakteristik pembelajaran Abad XXI pada TVET dimana karakteristik filosofi pragmatisme menekankan pemecahan masalah berpikir orde tinggi, filosofi pragmatisme juga meletakkan pendidikan sebagai interaksi aktif memandirikan peserta didik dalam belajar memecahkan masalah.

Para filsuf yang berhubungan dengan pragmatisme yakni Peirce yang dipandang sebagai penggagas pragmatisme, James sebagai pengembangnya dan Dewey yang menerapkan pragmatisme. Airan pragmatisme mempunyai relevansi yang tinggi dalam pendidikan kejuruan dalam menumbuhkan kemampuan peserta didik untuk berpikir kritis, mandiri dan mampu mengatasi permasalahan-permasalahan yang terjadi dalam hidupnya.

George Count dan Harold Rugg menggagas untuk membangun masyarakat baru yang pantas dan adil pada tahun 1930, gagasan ini selanjutnya didukung dengan pemikiran progresif Dewey, dan menjelaskan aliran rekonstruksionisme berlandaskan filsafat pragmatisme (Teguh Wangsa, 2011:190). Kata rekonstruksionisme berasal dari bahasa inggris reconstruct yang memiliki arti menyusun kembali. Pada konteks filsafat rekonstruksionisme aliran yang ini berkeingian untuk merombak tata susunan lama dengan membangun tata susunan hidup baru yang bernuansa modern. Menurut John Hendrik (Muhmydaieli, 2011:173) rekonstrusionisme adalah reformasi sosial yang menghendaki budaya modern para pendidik. Tokoh aliran reconstructionis yakni Dewey, Braeld, Freire dan Ivan Illic mengemukankan dua premis yakni, 1). masyarakat perlu rekonstruksi secara terus menerus dengan melakukan perubahan. 2) suatu perubahan sosial akan mengakibatkan rekonstruksi pendidikan dan peran pendidikan dalam merekonstruksi masyarakat (Wagiran:2007).

Pada pendidikan kejuruan yang juga mengalamai tranformasi perkembangan teknologi yang begitu cepat maka melalui filsafat konstruksionisme dapat digunakan dalam melengkapi dasar pijakan daam pendidikan kejuruan. Menurut Wagiran (2007) filsafat rekonstruksionisme relevan dengan perubahan teknologi, dalam kurikulum rekonstruksionisme dapat mengembangkan kemampuan menggunakan teknologi, dan juga mampu mengembangkan kemampuan kritis peserta didik yang dapat berfungsi sebagai penyeimbang penggunaan teknologi di masyarakat, disamping dapat membantu masyarakat memahami teknologi sesuai dengan bidangnya.

Dalam aliran filosofi pragmatism rekonstruksionis pengajar memberi kesempatan kepada peserta didik untuk belajar dari lingkungan sosial untuk belajar dimasyarakat, belajar berorganisasi yang nyata, ikut serta belajar yang tidak hanya dilingkup di sekolah saja, namun 
juga diluar sekolah misalnya industri sehingga mampu untuk memecahkan permasalahan yang ada di masyarakat maupun di dunia kerja. Berdasarkan dari penjelasan tersebut filosofi pragmatism rekonstruksionis menjadi salah satu pendukung TVET terutama di era perkembangan teknologi saat ini di era revolusi indutsri 4.0 dengan pembelajaran abad XXI yakni abad yang banyak mengalami perubahan.

\section{Pembelajaran Abad XXI di Era Revolusi industri 4.0 Pada Pendidikan Kejuruan \\ a. Pembelajaran Abad XXI}

Saat ini dahsyatya perubahan perkembangan teknologi berdampak juga pada pendidikan kejuruan, abad XXI adalah Abad penuh perubahan. Dalam kontek pembelajaran Abad XXI menurut Trilling \& Fadel (2009) kompetensi Abad XXI mencakup: 1) pembelajaran dan keterampilan inovasi terdiri dari penguasan pengetahuan dan keterampilan yang beragam, berpikir kritis dan penyelesaian masalah, komunikasi dan kolaborasi saling bekerjasama, dan kreatifitas dan inovasi, 2) keterampilan literasi digital yakni literasi informasi, literasi media, dan literasi ICT, 3) karir dan kecakapan hidup teridiri dari fleksibilitas dan adaptabilitas, inisiatif, interaksi sosial dan budaya, produktifitas dan akuntabilitas, kepemimpinan dan tanggung jawab.

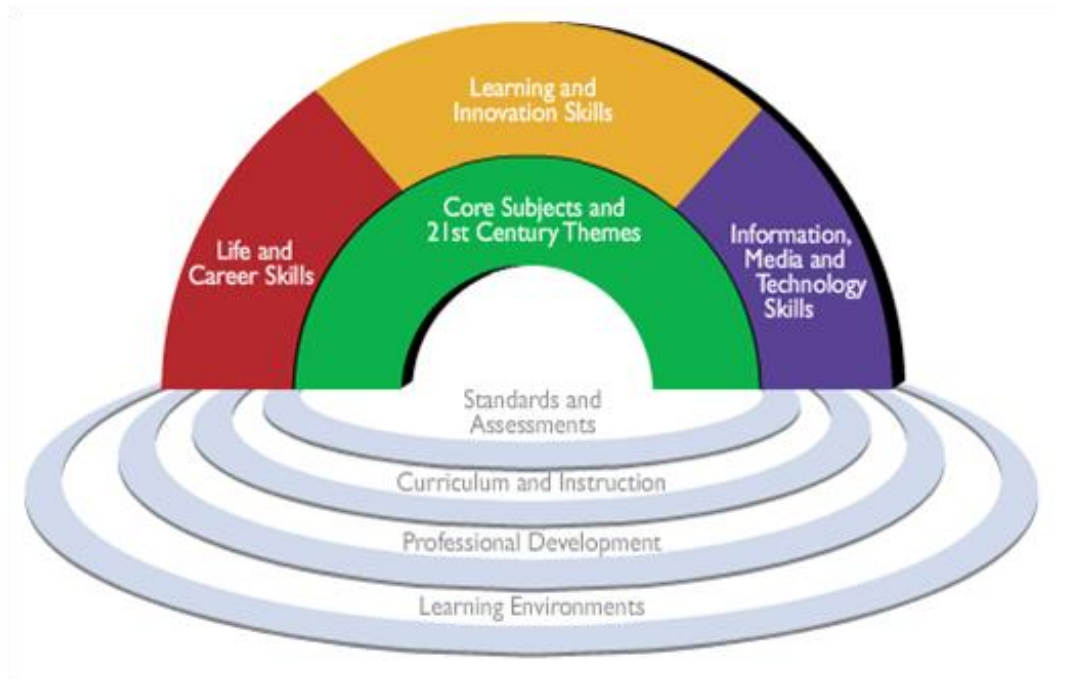

Gambar 1. Core Subject 21st Century Skills

Kompetensi Abad XXI tersebut sejalan menurut Sudira (2018) yang menjelaskan pekerjaan modern di Abad XXI membutuhkan skill pemecahan masalah secara kolaboratif lintas disiplin ilmu, lintas bidang, lintas ruang, dan waktu. Selain itu memperlukan kerjasama untuk berkolaborasi, komunikasi efektif, kreativitas, kemampuan berpikir kritis, penguasaan media dan teknologi informasi, inovasi merupakan aspek-aspek penting dalam pengembangan pembelajaran TVET saat ini dan dimasa depan. Maka dari itu untuk menghadapi Abad XXI penguasaan multi kompetensi atau skill dan pengetahuan harus diterapkan secara baik di sekolah/perguruan tinggi dan dunia kerja. Serta muatan pembelajaran Abad XXI menyesuaikan dengan perubahan di era industri 4.0 berbasis sains, teknologi dan rekayasa.

Saat ini dunia telah memasuki era discruption dimana kemajuan teknologi memungkinkan terjadinya otomatisasi di berbagai bidang termaksud dalam pendidikan kejuruan. Revolusi Industri 4.0 ditandai dengan perpaduan teknologi seperti internet of things, advanced robotics, 3D printing, artificial intelligence, virtual and augmented reality. Oleh karena itu pendidikan kejuruan saat ini menghadapi tantangan yang cukup besar, tranformasi penggunaan teknologi yang lebih dominan menjadi berbagai bidang pekerjaan yang awalnya diisi tenaga manusia tergantikan dengan teknologi, mesin, maupun kecerdasan buatan. Maka dari itu pendidikan kejuruan mesti mempersiapkan segala hal dalam menghadapi transisi ini.

\section{b. Sejarah Revoluasi industri 4.0}

Era revolusi industri 4.0 dikenal juga dengan istilah revolusi digital dan era disrupsi teknologi. Istilah Industri 4.0 resmi lahir di Jerman pada saat diadakan Hannover Fair pada tahun 2011 (Kagermann dkk, 2011). Sejarah revolusi industri berawal dari industri 1.0, 2.0, 3.0, hingga revolusi industri 4.0. Pada Industri 1.0 ditandai dengan mekanisasi produksi untuk 
menunjang efektifitas dan efisiensi aktivitas manusia,untuk industri 2.0 ditandai dengan produksi massal dan standarisasi mutu, sedangkan pada industri 3.0 ditandai dengan penyesuaian massal dan fleksibilitas manufaktur berbasis otomasi dan robot. Selanjutnya di era saat ini muncul istilah Industri 4.0 yang ditandai dengan cyber fisik dan kolaborasi manufaktur (Hermann et al, 2015; Irianto, 2017).

Revolusi Industri 4.0 menjadi era baru perindustrian yang banyak menggunakan teknologi virtual dan canggih, sehingga di era ini menjadi pendorong munculnya ide-ide baru, ciptaan baru maupun sesuatu yang lama diodifikasi untuk berinovasi dalam mengembangkan teknologi baru yang memberikan dampak disrupsi terhadap kehidupan masyarakat. Menurut Hermann et al, 2016 berdasarkan gambar 1.menunjukan perinsip industri 4.0 terdiri dari prinsip bantuan teknis seperti bantuan virtual dan fisik, prinsip interkoneksi meliputu kolaborasi, standar, dan keamanan, prinsip transparasi informasi yakni analisis data dan penyediaan informasi serta prinsip keputusan yang terdesentrlisasi.

\section{c. Tantangan dan Peluang Revolusi industri 4.0 Pada Pendidikan Kejuruan}

Hadirnya revolusi industri 4.0 memunculkan berbagai tantangan dan tuntutan yang tidak dapat dihindarkan. Dalam menghadapi tantangan dan peluang industri 4.0 pendidikan kejuruan harus terus berkembang secara dinamis berinovasi dan kreasi. Hadapi industri 4.0 tantangan pendidikan kejuruan semakin kompleks, Wolter mengidentifikasi tantangan industri 4.0 meliputi; 1) masalah keamanan teknologi informasi; 2) keandalan dan stabilitas mesin produksi; 3) kurangnya keterampilan yang memadai; 4) keengganan untuk berubah dari para pemangku kepentingan; dan 5) hilangnya banyak pekerjaan karena telah berubah menjadi otomatisasi yang menngunakan peran teknologi (Sung, 2017).

Untuk menjawab tantangan tranformasi pendidikan industri 4.0 pada pendidikan kejuruan juga harus memikirkan langkah-langkah apa saja yang harus dilakukan. Tentu langkah-langkah tersebut melibatkan seluruh pemangku kepentingan untuk menjawab tantangan pada pendidikan 4.0 ini. Dalam menjawab tantangan industri 4.0. Menurut Bukit (2014) pendidikan kejuruan harus memiliki karakteristik yang meliputi; 1) berorientasi pada kinerja individu dalam dunia kerja; 2) justifikasi khusus pada kebutuhan nyata di lapangan; 3) fokus kurikulum pada aspek-aspek psikomotorik, afektif, dan kognitif; 4) tolok ukur keberhasilan; 5) kepekaan terhadap perkembangan dunia kerja; 6) memerlukan sarana dan prasarana yang memadai; dan 7) serta dukungan masyarakat.

Multi kompetensi dan pengetahuan di abad XXI dan era industri 4.0 yang dibutuhkan harus diintegrasikan ke dalam elemen pendidikan kejuruan. Kebijakan pemerintah untuk revitalisasi pendidikan kejuruan Indonesia harus mencakup Chronosystem Pendidikan Kejuruan Era Industri 4.0 yakni 1) sistem pembelajaran, 2) satuan pendidikan, 3) peserta didik, dan 4) pendidik dan tenaga kependidikan juga dibutuhkan (Muhamad Yahya, 2018).

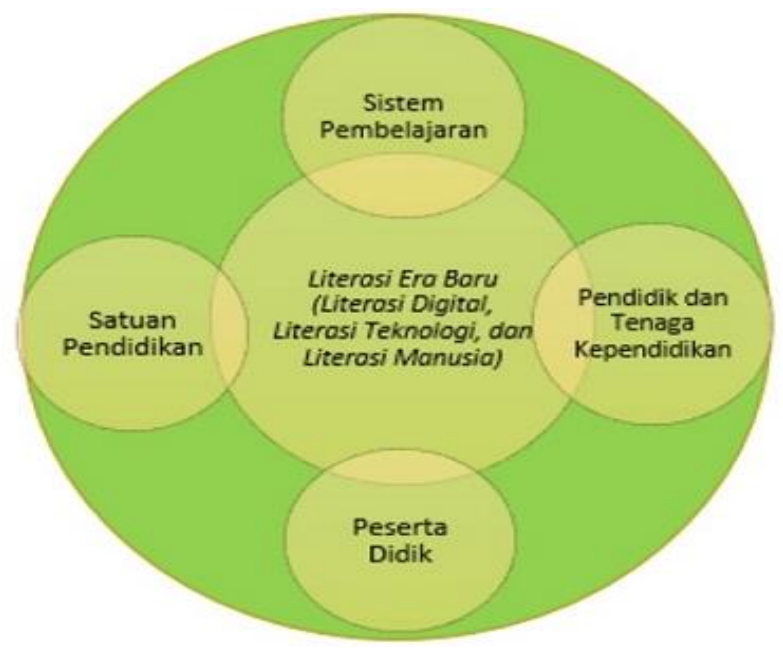

Gambar 2. Chronosystem Pendidikan Kejuruan Era Industri 4.0 
Berdasrakan gambar 2, pada komponen sistem pembelajaran, satuan pendidikan, peserta didik, pendidik dan tenaga kependidikan saling integrasi dalam suatu sistem pendidikan kejuruan, selaras dan saling keterakitan untuk berperan dalam menyongsong perubahan dalam menghasilkan SDM yang siap kerja untuk menghadai era Industri 4.0.

\section{d.Pebelajaran Revolusi industri 4.0 di Pendidikan Kejuruan}

Transformasi digital dirasakan perlu untuk kemajuan dunia pendidikan di Indonesia, sama halnya percepatan adaptasi revolusi industri 4.0 di lingkungan pendidikan kejuruan sangat diperlukan terutama dalam pembelajaran yang mencakup kompetensi Abad XXI dan selaras dengan peranan TVET sebagai pendidikan dan pelatihan yang tujuanya mempersiapkan tenaga kerja sesuai kebutuhan dunia kerja.

Hibridisasi proses belajar saat ini sudah bukan hal yang tabu untuk dilakukan di era milenial.Proses pembelajaran yang terpusat pada peserta didik dan menggunakan teknologi dengan jangkauan tidak terbatas yang mampu melewati jarak, ruang dan waktu. Pengetahuan dan keterampilan yang diperoleh melalui teknologi juga memungkinkan peserta didik mampu memperolehnya ilmu pengetahuan langsung secara luas. Lompatan inovasi dan kemajuan industri 4.0 dipicu oleh bidang bidang, Artificial Intelligence, Robotics, Internet of Things, Autonomous Vehicles, Biotechnology, Nanotechnology, 3-D Printing, Material Science, Quantum Computing, dan Energy Storage. Lebih lanjut proses transformasi pendidikan mengarah pada Pedagogi (education 1.0), Andragogi (education 2.0), Andragogi dengan mobile learning (education 3.0), dan Heutagogi (education 4.0) (Ratna wardani: 2018).

Menristekdikti Muhamad Nasir (2018) pada Peningkatan Mutu Vokasi Dalam Menghadapi Era Revolusi Industri 4.0. Dicanangkanya aktivitas utama revitalisasi pendidikan tinggi vokasi melalui aktivitas: 1). Revisi kurikulum PT, 2). Penyiapan dosen industri, 3). Implemnetasi dual system 3-2-1, 4). Pembangunan teaching factory.5). Retooling dan sertifikasi dosen program vokasi. 7). Sertifikat Lulusan PT Vokasi. 8). Penyediakan guru SMA Produktif.

Solusi dari pembelajaran 4.0 menurut Didin wahidin Direktur Kemahasiswaan Ditjen belmawa kemenristekdikti (2018) penguasaan kompetensi 4.0 perlunya gerakan literasi baru menghadapi era revolusi industri 4.0 seperti literasi data, literasi teknologi dan literasi manusia.Tiga keterampilan kompetensi ini diprediksi menjadi keterampilan yang sangat dibutuhkan di era industri 4.0 pada pendidikan tinggi vokasi maupun di kejuruan. Adaptasi gerakan literasi baru dapat diintegrasi dengan melakukan penyesuaian kurikulum dan sistem pembelajaran sebagai respon terhadap era industri 4.0 yang perlu dikembangkan untuk pendidikan kejuruan baik SMK maupun pendidikan tinggi di pembelajaran abad XXI.

Ditengah perkembangan teknologi yang super cepat dibidang pendidikan mengalami dirupsi luar biasa, muncul massive open online course (MOOC) secara drastis mengubah cara pandang dan praksis pendidikan di seluruh dunia, termaksud MOOC juga telah dikembangkan di Indonesia. Dimana pembelajaran dapat dilakukan secara online terbuka bagi siapa saja, dimana saja, dan kapan saja tanpa dibatasi ruang dan waktu. Selain itu di abad XXI ini pembelajaran berpusat pada peserta didik sehingga peserta didik mengkonstruksi pengetahuannya sendiri sedangkan peran pengajar sebagai fasilitator untuk membimbing peserta didik. Muhamad Nasir (2018) memberikan solusi pembelajaran 4.0 degan cara blended learning yakni Face to face, Blended dan online learning, melalui solusi tersebut maka dapat menggunakan pembelajaran elektronik (e-learning).

E-learning yang diterapkan dalam pendidikan kejuruan tentunya harus matching dengan kompetensi tertentu, sehingga tidak semua komptensi pembelajaran bisa diterapkan menggunakan e-learning, selain itu e-learning juga bisa digunakan saat peserta didik melakukan prakrin di tempat kerja, peserta didik dapat belajar ataupun berkomunikasi melalui e-learning, sehingga pembelajaran tidak terbatas jarak, ruang dan waktu."E-learning has provided away to improve access for remote communities to connect to vocational education institutions hundreds of kilometres away.". Berdasarkan definisi terbut berarti melalui e-learning dapat memberikan akses bagi masyarakat terpencil untuk terhubung ke lembaga pendidikan kejuruan dengan jarak ratusan kilometer jauhnya (Catts dkk., 2011:105). Hak ini berarti dengan adanya e-learning secara tidak langsung masyarakat dapat tetap belajar di pendidikan kejuruan meski terhalang oleh jarak yang jauh.

\section{Kesimpulan}


Di Indonesia pendidikan kejuruan untuk jenjang sekolah menengah kejuruan dan pendidikan vokasi untuk pendidikan tinggi. Praksis pendidikan kejuruan dunia di motori dua tokoh terkemuka yaitu Charles Prosser dan John Dewey. Secara filosofis tujuan pendidikan vokasi yakni esensialisme, pragmatis, dan pragmatis rekonstruksi. Di Indonesia sendiri pada pendidikan kejuruan lebih cendrung mengarah penggunaan mazab Prosser melalui filosfi esensialisme dan mazab Dewey filosofi pragmatis. Perubahan-perubahan yang terjadi dalam pembelajaran Abad XXI memberi tantangan pada TVET dimana terjadinya pergeseran paradigma pengembangan sumber daya manusia melalui revolusi teknologi informasi dan komunikasi, pada kaspitas ini TVET cenderung kefilosofi pragmatism dalam menghadapi masa depan, dan pragmatis rekonstruksi yang berkaitan dengan perkembangan teknologi. Revolusi industri 4.0 yang identik dengan perkembangan teknologi yang super cepat, mau tidak mau pendidikan kejuruanpun harus mampu menghadpi transisi ini, maka sangat diperlukannya pembelajaran yang mencakup kompetensi Abad XXI dan selaras dengan peranan TVET sebagai pendidikan dan pelatihan yang tujuanya mempersiapkan tenaga kerja sesuai kebutuhan dunia kerja.

\section{DAFTAR PUSTAKA}

Bukit, M. (2014). Strategi dan inovasi pendidikan kejuruan dari kompetensi ke kompetisi. Bandung: Alfabeta.

Catts,R., lan, F.s \& Ruth,W. (2011). Vocational learning innovative theory and practice. London:Springer Dordrecht Heidelberg.

Departemen Pendidikan Nasional,Peraturan Pemerintah Republik Indonesia Nomor 19 tahun 2005 tentang Standar Nasional pendidikan, Jakarta: Departemen Pendidikan Nasional, 2005

Depdiknas .2003. Undang-undang $R I$ No.20 tahun 2003.tentang sistem pendidikan nasional.Gandhi HW, Teguh Wangsa, 2011, Filsafat Pendidikan: Mazhab-Mazhab Filsafat Pendidikan, Ar-Ruzz Media, Yogyakarta.

Didin wahidin. 2018. Direktur kemahasiswaan Ditjen belmawa Kemenristekdikti. Mencari format kegiatan kemahasiswaan di era revolusi industri 4.0.

Hermann, M., Pentek, T., \& Otto, B. (2016). Design Principles for Industrie 4.0 Scenarios. Presented at the 49th Hawaiian International Conference on Systems Science.

Irianto, D. (2017). Industry 4.0; The Challenges of Tomorrow. Disampaikan pada Seminar Nasional Teknik Industri, Batu-Malang.

Jama Jalius (2010) Dialog Seminar Filsafat Pendidikan: Program Pasca Sarjana Fakultas Teknik Universitas Negeri Padang.

Kagermann, H., Lukas, W.D., \& Wahlster, W. (2011). Industrie 4.0: Mit dem Internet der Dinge auf dem Weg zur 4. industriellen Revolution.

Muhammad yahya, Orasi IImiah Professor bidang IImu Pendidikan Kejuruan Universitas Negeri Makassar Tanggal 14 Maret 2018.

Muhamad Nasir. (2018). Peningkatan mutu vokasi dalam Menghadapi era revolusi industri 4.0 Kementerian Riset, Teknologi, dan Pendidikan Tinggi.

Muhmidayeli. (2011). Filsafat Pendidikan. Bandung: Refika Aditama.

Ratna Wardani. 2018.21stCentury Educator:Menyongsong Transformasi Pendidikan4.0.Disampaikan pada seminar nasional dinamika informatika senadi UPY 2018 
Rojewski. J.W (2009). A conceptual framework for technical and vocational education and training. In R. Maclean, D. Wilson, \& C. Chinien (Eds.), International Handbook of Education for the Changing World of Work, Bridging Academic and Vocational Learning (pp. 19-40). Bonn: Springer.

Sudira (2016).TVET abad XXI filosofi, teori, konsep, dan strategi pembelajaran vokasionaL. Yogyakarta. UNY Press.

Sudira (2018).Metodelogi Pembelajaran Vokasional Abad XII. Yogyakarta. UNY Press.

Sung, T.K. (2017). Industri 4.0: a Korea perspective. Technological Forecasting and Social Change Journal, 1-6.

Trilling, B \& Fadel, C. (2009). 21st-century skills: learning for life in our times. US: Jossey-Bass A Wiley Imprint.

Wagiran, 2007. Telisik Aliran Filsafat Pendidikan : Implikasinya dalam Pengembangan Kurikulum dan Pembelajaran Kejuruan. Disampaikan dalam Seminar Nasional Telisik Hambatan Pelaksanaan SMK dan Solusinya, Jurusan Pendidikan Teknik Mesin UNNES, Tanggal 27 Januari 2007. 